Volume 3, Nomor 1, Juni 2020

\title{
Pengembangan Video Pembelajaran untuk Meningkatkan Hasil Belajar pada Mata Pelajaran Teknologi Jaringan Berbasis Luas (WAN) Kelas XI di SMK Negeri 1 Kempas
}

\author{
Dwi Cahyono ${ }^{1}$, Afis Pratama ${ }^{2}$, Handini Arga Damar Rani ${ }^{3}$ \\ ${ }^{1}$ Dwi Cahyono, ${ }^{2}$ Afis Pratama, ${ }^{3}$ Handini Arga Damar Rani \\ SMAN Dharma Pendidikan Kempas, Universitas IVET \\ Email: dwic878@ gmail.com \\ Diterima: Mei , Disetujui:Juni Dipublikasi:Juni 2020
}

\begin{abstract}
ABSTRAK
Penelitian ini bertujuan untuk (1) Mengetahui cara pembuatan atau perancangan video pembelajaran pada Kompetensi Dasar Mengkonfigurasi Jaringan Nirkabel pada Mata Pelajaran Teknologi Jaringan Berbasis Luas (WAN); (2) Mengetahui kelayakan video pembelajaran pada Kompetensi Dasar Mengkonfigurasi Jaringan Nirkabel pada Mata Pelajaran Teknologi Jaringan Berbasis Luas (WAN); (3) Mengetahui hasil pengujian produk video pembelajaran yang dihasilkan kepada Peserta Didik Kelas XI. Penelitian Research and Development $(R \& D)$, dengan tahapan pengembangan yang terdiri atas 6 tahapan yaitu (1) Concept yang meliputi identifikasi masalah dan analisa kebutuhan; (2) Design (merancang tampilan); (3) Material collecting (pengumpulan bahan-bahan untuk membuat media); (4) Assembly (penggabungan atau penyatuan bahan); (5) Testing (uji kelayakan media); (6) Distribution (distribusi ke peserta didik dengan upload di youtube). Teknik analisis data yang digunakan adalah teknik analisis deskriptif kuantitatif yaitu dengan menganalisis data kuantitatif yang diperoleh dari angket uji ahli dan uji lapangan. Data kuantitatif yang berupa angka-angka hasil perhitungan atau pengukuran diproses dengan cara dijumlah kemudian dibandingkan dengan jumlah yang diharapkan sehingga diperoleh persentase kelayakan. Hasil penilaian kelayakan pengembangan video pembelajaran untuk Kompetensi Dasar Mengkonfigurasi Jaringan Nirkabel ini adalah: (1) Persentase skor penilaian dari ahli materi sebesar 89\%, (2) Persentase skor penilaian dari ahli media sebesar $77 \%$, (3) Persentase skor tanggapan dari siswa sebesar $81 \%$. Berdasarkan hasil penilaian dan tanggapan yang diperoleh tersebut dapat disimpulkan bahwa media pembelajaran video tutorial untuk Kompetensi Dasar Mengkonfigurasi Jaringan Nirkabel ini sangat layak untuk digunakan dan dikembangkan. Hasil dari evaluasi setelah menonton video pembelajaran terjadi peningkatan hasil belajar sebesar 15\%.
\end{abstract}

\section{Kata Kunci : media pembelajaran, video pembelajaran, jaringan nirkabel}

\section{ABSTRACT}

The purpose of this research is to (1) Learn how to create or design learning videos on the Basic Competencies of Configuring Wireless Networks in Broad-Based Network Technology (WAN) Subjects; (2) Understanding the feasibility of learning videos on the Basic Competencies of Configuring Wireless Networks in Broad-Based Network Technology (WAN) Subjects; (3) Know the results of testing video learning products produced by the State SMI Class XI Participants 1 Campaign on Broad-Based Network Technology (WAN) Subjects. Research and Development (R\&D) research, with development stages consisting of 6 stages namely (1) Concept which includes problem identification and needs analysis; (2) Design (designing the display); (3) Material collecting (collection of materials for making media); (4) Assembly (incorporation or consolidation of materials); (5) Testing; (6) Distribution (distribution to learners with uploads on youtube). The data analysis technique used is a quantitative descriptive analysis technique by analyzing the quantitative data obtained from the expert test and field test. Quantitative data in the form of numerical results or measurements are processed in a numerical way and then compared to the expected amount to obtain a percentage of eligibility. The results of the video development eligibility assessment for the Basic Competencies of Configuring the Wireless Network were: (1) Percentage of material expert rating of $89 \%$, (2) Media grade student rating of $77 \%$, (3) Student response percentage of $81 \%$. Based on these results and the results it can be concluded that this video learning media tutorial for Basic Competencies in Configuring this Wireless Network is well worth using and developing. The result of the evaluation after watching the video was a $15 \%$ increase in learning outcomes. 
Keywords: learning media, video learning, wireless networks

\section{PENDAHULUAN}

Sekolah Menengah Kejuruan merupakan sekolah yang menginginkan lulusannya mempunyai kompetensi keahlian sesuai dengan jurusan yang dipilih oleh peserta didik. Di SMK bukan hanya sekedar "bisa", namun seyogyanya harus benarbenar menguasai kompetensi keahlian. Untuk itu selama menempuh pendidikan peserta didik harus benar-benar digembleng untuk menguasai keahlian yang dipilihnya.

Salah satu indikator bahwa peserta didik dikatakan berhasil apabila dalam evaluasi pembelajaran mendapatkan nilai diatas Kriteria Ketuntasan Minimal (KKM) yang telah ditetapkan oleh sekolah. Standar Penilaian ini juga digunakan di SMK Negeri 1 Kempas.

Dari data awal yang didapatkan, sebanyak 12 siswa yang telah mencapai nilai KKM dari 30 peserta didik, artinya $40 \%$ yang telah berhasil mencapai nilai KKM. Hal ini dikarenakan di perpustakaan SMK Negeri 1 Kempas masih sangat minim Buku Literatur pada pembahasan jaringan nirkabel. Disamping itu media pembelajaran yang digunakan masih menggunakan papan tulis dan PowerPoint sehingga guru kesulitan dalam menyampaikan materi karena yang ditampilkan di media pembelajaran hanya berupa barisan-barisan teks. Materi yang dibahas dalam Mengkonfigurasi Jaringan Nirkabel antara lain konfigurasi radio, konfigurasi router, konfigurasi access point. Dengan media tersebut peserta didik dalam mengikuti proses pembelajaran masih rendah karena materi yang disampaikan tidak menarik.

Di SMK Negeri 1 Kempas belum ada guru yang memanfaatkan media video pembelajaran. Hal ini dikarenakan guru banyak yang belum mengerti software yang digunakan untuk membuat video pembelajaran. Kendala lainnya yaitu peralatan untuk praktik peserta didik masih kurang sehingga ketika melakukan praktikum peserta didik banyak yang mengobrol untuk menunggu giliran melakukan praktik. Tentu hal itu sangat tidak efektif dalam proses belajar mengajar. Padahal mata pelajaran Teknologi Jaringan Berbasis Luas (WAN) merupakan Pelajaran Dasar tentang jaringan yang tentunya akan menjadi pondasi utama dalam menempuh mata pelajaran produktif selanjutnya. Jika peserta didik belum memahami materi pada kompetensi ini tentu pada pembahasan selanjutnya akan semakin bingung karena materi pelajaran produktif merupakan materi yang berkelanjutan. Pada Mata Pelajaran Teknologi Jaringan Berbasis Luas (WAN) di pokok bahasan Kompetensi Dasar Mengkonfigurasi Jaringan Nirkabel peserta didik dituntut untuk menguasai setting jaringan point to point, setting mikrotik dan setting access point.

Permasalahan dalam penelitian dirumuskan sebagai berikut: (1) Bagaimana membuat video pembelajaran pada Kompetensi Dasar Mengkonfigurasi Jaringan Nirkabel pada Mata Pelajaran Teknologi Jaringan Berbasis Luas (WAN)? (2) Bagaimana kelayakan video pembelajaran pada Kompetensi Dasar Mengkonfigurasi Jaringan Nirkabel pada Mata Pelajaran Teknologi Jaringan Berbasis Luas (WAN)? (3) Bagaimana hasil pengujian produk video pembelajaran yang dihasilkan kepada Peserta Didik Kelas XI SMK Negeri 1 Kempas pada Mata Pelajaran Teknologi Jaringan Berbasis Luas (WAN)?

Tujuan dari penelitian ini adalah sebagai berikut: (1) Pengembangan video pembelajaran pada Kompetensi Dasar Mengkonfigurasi Jaringan Nirkabel pada Mata Pelajaran Teknologi Jaringan Berbasis Luas (WAN). (2) Mengetahui kelayakan video pembelajaran pada Kompetensi Dasar Mengkonfigurasi Jaringan Nirkabel pada Mata Pelajaran Teknologi Jaringan Berbasis 
Luas (WAN). (3) Mengetahui hasil pengujian produk video pembelajaran yang dihasilkan kepada Peserta Didik Kelas XI SMK Negeri 1 Kempas pada Mata Pelajaran Teknologi Jaringan Berbasis Luas (WAN).

Penelitian ini terkait dengan Penelitian Yogi Nurcahyo Dinata, Jurusan Pendidikan Teknik Sipil dan Perencanaan, Fakultas Teknik, Universitas Negeri Yogyakarta Tahun 2013 yang berjudul Penggunaan Media Pembelajaran Video Tutorial Untuk Meningkatkan Hasil Belajar Siswa Teknik Gambar Bangunan SMK N 1 Seyegan Pada Mata Pelajaran Menggambar Dengan Autocad. Hasil penelitian menunjukkan bahwa untuk merancang pengembangan media pembelajaran video tutorial ini diperlukan tahapan-tahapan yang harus dilakukan dari mulai pengumpulan informasi, membuat desain awal produk, melakukan validasi, uji coba, uji efektivitas, sampai terciptanya produk akhir. Berdasarkan penilaian dari ahli media sebesar 81,9\% dan ahli materi sebesar 82,3\% yang masuk kategori baik, media pembelajaran video tutorial ini layak digunakan sebagai media pembelajaran pada mata pelajaran menggambar dengan autocad. Hasil penelitian juga menunjukkan terdapat perbedaan dimana hasil belajar siswa yang menggunakan video tutorial lebih tinggi dibanding yang menggunakan media konvensional. Dengan demikian, media pembelajaran video tutorial ini efektif dalam meningkatkan hasil belajar siswa pada mata pelajaran menggambar dengan autocad, sehingga layak untuk dikembangkan.

Dan Penelitian Aria Pramudito, Jurusan Pendidikan Teknik Mesin, Fakultas Teknik, Universitas Negeri Yogyakarta Tahun 2013 yang berjudul Pengembangan Media Pembelajaran Video Tutorial pada Mata Pelajaran Kompetensi Kejuruan Standar Kompetensi Melakukan Pekerjaan dengan Mesin Bubut Di SMK Muhammadiyah 1 Playen. Dari penelitian yang telah dilakukan diperoleh hasil sebagai berikut; Hasil penilaian kelayakan media pembelajaran video tutorial untuk standar kompetensi melakukan pekerjaan dengan mesin bubut ini adalah: (1) Persentase skor penilaian dari ahli materi 1 sebesar 76,79\% dan ahli materi 2 sebesar 82,14\%; (2) Persentase skor penilaian dari ahli media 1 sebesar $72,22 \%$ dan ahli media 2 sebesar 80,56\%; (3) Persentase skor tanggapan dari reviewer mahasiswa sebesar 84,33\%; dan (4) Persentase skor tanggapan dari siswa sebesar $80,18 \%$. Berdasarkan hasil penilaian dan tanggapan yang diperoleh tersebut dapat disimpulkan bahwa media pembelajaran video tutorial untuk standar kompetensi melakukan pekerjaan dengan mesin bubut ini layak untuk digunakan dan dikembangkan.

Serta Penelitian Muzakki, Ahsan. \& Putu Asto Buditjahjanto, I Gusti Tahun 2015 dengan judul Pengembangan Media Pembelajaran Video Tutorial Teknik Pemrograman Kelas X Bidang Keahlian Teknik Audio Video SMK Negeri 1 Madiun. Dari penelitian yang telah dilakukan diperoleh hasil sebagai berikut; Hasil validasi yang melibatkan tiga Validator memperoleh hasil 85,5915\%, sehingga kelayakan dari media pembelajaran video tutorial termasuk dalam kategori sangat baik. Hasil respon siswa terhadap media pembelajaran video tutorial memperoleh hasil $83,7 \%$, sehingga media pembelajaran video tutorial mendapatkan respon yang sangat baik dari para siswa. Hasil belajar yang dilakukan dalam penelitian ini diambil dari dua kelompok, yaitu kelompok tanpa perlakuan dan kelompok dengan perlakuan. Kelompok tanpa perlakuan memperoleh hasil rata - rata 69,7 , sedangkan kelompok dengan perlakuan memperoleh hasil 75,7. Setelah dilakukan uji-t maka diperolehlah hasil t-hitung -2,062 dan t-tabel -1,70, sehingga sesuai dengan hipotesis yang telah dibuat, maka dinyatakan terdapat perbedaan hasil belajar antara kelompok tanpa 
perlakuan dan kelompok dengan perlakuan. Dengan demikian media pembelajaran layak untuk dikembangkan.

Dan Penelitian Anwar Efendi, Sri Sumarni dan Agus Efendi Tahun 2016 yang berjudul Pengembangan Media Pembelajaran Berbasis Video Tutorial Pada Mata Kuliah Mekanika Tanah. Hasil penelitian menunjukkan bahwa tersusunnya media pembelajaran berbasis video tutorial pada mata kuliah mekanika tanah dengan tingkat kelayakan berdasarkan penilaian ahli materi diperoleh persentase sebesar 79,58\% termasuk kategori layak, penilaian ahli media diperoleh persentase sebesar 77, $5 \%$ termasuk kategori layak, penilaian ahli pembelajaran dengan persentase sebesar 86, $13 \%$ termasuk kategori sangat layak. Hasil uji coba terbatas hasil yang diperoleh persentase sebesar 86,13\% termasuk kategori sangat layak. Hasil uji coba luas diperoleh persentase sebesar 75, 867\% termasuk kategori layak. Dengan demikian media pembelajaran layak untuk dikembangkan.

Selain itu juga ada Penelitian Yana, Baiq Ade Irma Willi., Kholisho, Yosi Nur., \& Fathoni, Ahmad Tahun 2018 yang berjudul Pengembangan Media Pembelajaran Berbasis Video Tutorial Interaktif pada Mata Pelajaran Teknik Animasi 2 Dimensi. Hasil penelitian: (1) media pembelajaran berbasis vidio tutorial interaktif yang dikembangkan berupa software dikemas dalam bentuk file .exe dan CD interaktif. (2) Media pembelajaran berbasis video tutorial layak digunakan dalam proses pembelajaran, berdasarkan hasil validasi dari ahli media memperoleh persentase sebesar 86,69\%, ahli materi sebesar $82,81 \%$, dan uji coba produk sebesar $75,93 \%$ dan uji coba pemakaian memperoleh persentase sebesar 79,89\%. Secara keseluruhan media pembelajaran berbasis video tutorial interaktif memperoleh persentase sebesar $76,66 \%$ dalam kategori kelayakan media "Sangat Layak".

\section{METODE PENELITIAN}

Penelitian ini merupakan jenis penelitian pengembangan (Research \& Development) yang berarti penelitian ini merupakan penelitian yang berorientasi pada produk. Produk yang dikembangkan dalam penelitian ini berupa media pembelajaran video tutorial.

Sampel pada penelitian ini adalah seluruh kelas XI Jurusan Teknik Komputer dan Jaringan SMK Negeri 1 Kempas Indragiri Hilir Riau.

Prosedur dalam penelitian ini menggunakan Model pengembangan multimedia Luther-Sutopo 2003 dalam (Iwan Binanto 2010: 259) yaitu pengembangan sistem multimedia dilakukan berdasarkan enam tahap yaitu: concept, design, material collecting, assembly, testing, dan distribution.

Instrumen pengumpulan data yang digunakan dalam penelitian ini adalah lembar evaluasi berupa angket. Suharsimi Arikunto (1993) menjelaskan bahwa angket adalah sejumlah pertanyaan tertulis untuk memperoleh informasi dari responden dalam dalam arti laporan tentang pribadinya, atau hal-hal yang diketahui. Analisis dari hasil observasi dalam studi lapangan bisa langsung diinterpretasikan karena pertanyaan yang diberikan kepada responden bersifat terbuka.

Hasil analisis data digunakan sebagai dasar untuk merevisi produk media yang dikembangkan. Metode analisis data dilakukan dengan menggunakan teknik analisis deskriptif kuantitatif, yaitu dengan menganalisis data kuantitatif yang diperoleh dari angket uji ahli dan uji lapangan.

Menurut Suharsimi Arikunto (2013), data kuantitatif yang berupa angka-angka hasil perhitungan atau pengukuran diproses 
dengan cara dijumlah kemudian dibandingkan dengan jumlah skor maksimum sehingga diperoleh persentase kelayakan. Rumus yang digunakan yaitu :

Persentase kelayakan (\%)

$$
=\frac{\text { Skor yang diperoleh }}{\text { Skor maksimum }} \times 100 \%
$$

Pencarian persentase dimaksudkan untuk mengetahui status sesuatu yang dipresentasikan dan disajikan tetap berupa presentase.

Tabel 1 Tabel Skala Persentase

\begin{tabular}{cc}
\hline $\begin{array}{c}\text { Persentase } \\
\text { pencapaian }\end{array}$ & Interpretasi \\
\hline $76-100 \%$ & Sangat layak \\
\hline $56-75 \%$ & Layak \\
\hline $40-55 \%$ & Cukup layak \\
\hline $0-39 \%$ & Kurang layak \\
\hline
\end{tabular}

\section{HASIL DAN PEMBAHASAN}

Dalam pelaksanaan penelitian dilakukan berdasarkan enam tahap yaitu: concept, design, material collecting, assembly, testing, dan distribution.

Pada tahap concept, penelitian diawali dengan melakukan proses identifikasi masalah pembelajaran yang ada di sekolah. Proses identifikasi masalah dimaksudkan untuk melihat permasalahanpermasalahan yang terjadi pada saat proses pembelajaran berlangsung. Hasil yang didapat dari proses identifikasi masalah inilah yang digunakan oleh peneliti dalam memilih tema penelitian. Setelah ditentukan tema penelitian yang akan dilakukan kemudian dilanjutkan dengan melakukan analisis kebutuhan. Baik itu kebutuhan akan media maupun kebutuhan akan materi.

Tahap pembuatan produk mencakup design, material collecting, assembly. Adapun proses pembuatan media video dilakukan melalui tiga tahap pembuatan, yaitu tahap penentuan aplikasi yang akan digunakan, output dari tipe file yang dibutuhkan, resolusi video yang diperlukan untuk menghasilkan gambar yang berkualitas.

Adapun hasil tampilan video seperti gambar berikut ini:

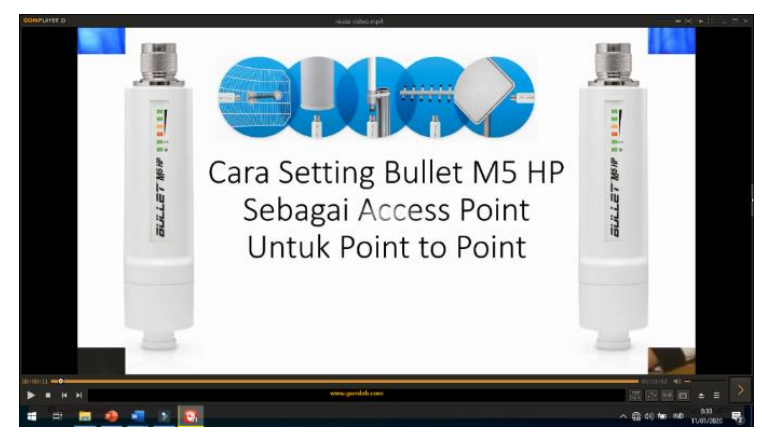

Gambar 2 Judul Video

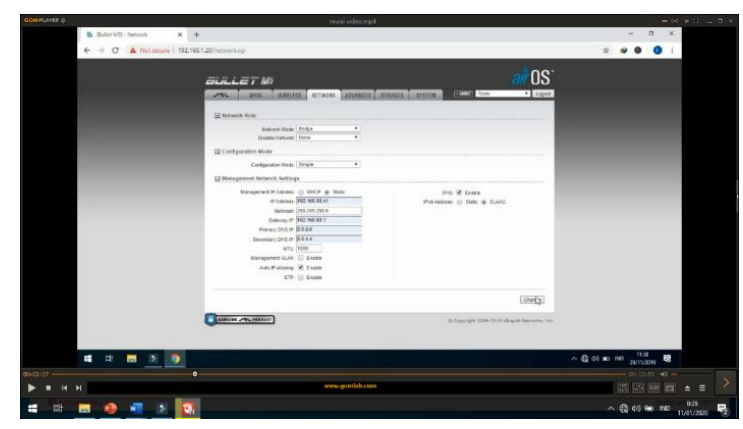

Gambar 3 Langkah-Langkah Konfigurasi

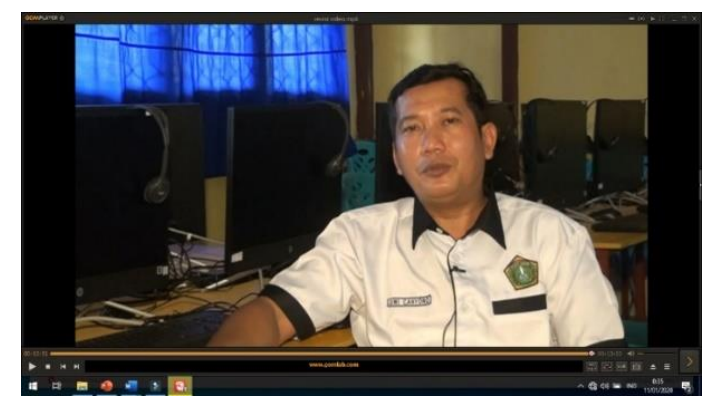

Gambar 4 Video Penutup

Tahap yang dilakukan selanjutnya adalah testing yang meliputi :

1. Pengujian oleh Ahli Media

Pengujian dilakukan oleh ahli media yaitu Guru Multi Media. Angket 
penilaian oleh ahli media meliputi tiga aspek yaitu aspek kualitas media, aspek penggunaan bahasa, aspek layout media. Grafik hasil validasi oleh ahli media ditunjukkan seperti gambar dibawah ini:

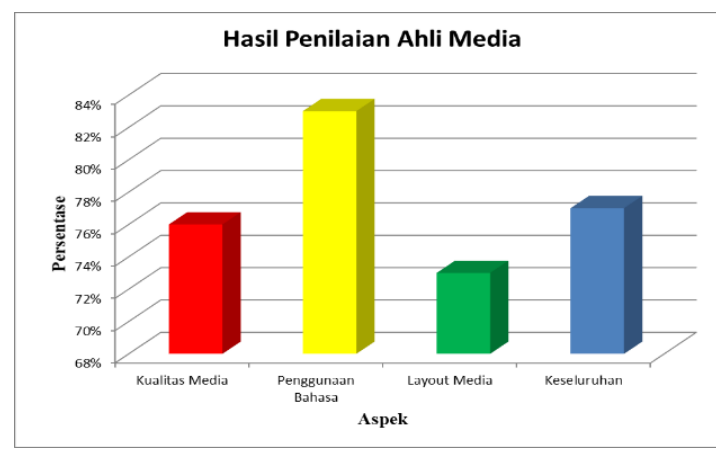

Gambar 5 Grafik Hasil Penilaian Ahli Media

Hasil penilaian ahli media ini ditinjau dari aspek: (1) Kualitas media, memperoleh persentasi (76\%), (2) Penggunaan bahasa, memperoleh persentasi (83\%), (3) Layout media memperoleh persentasi (73\%). Secara keseluruhan tingkat validasi oleh ahli media pada pembelajaran video tutorial memperoleh persentasi (77\%) berada dalam skala 1. Dengan demikian video tutorial ini dilihat dari medianya dikategorikan sangat layak diproduksi dengan revisi. Ahli media memberikan beberapa kritik dan saran untuk memperbaiki kualitas media diantaranya : Diawal video seharusnya ada judul/tampilan yang menarik dan pergantian pada transisi video dibuat efek yang lebih menarik.

\section{Pengujian oleh Ahli Materi}

Ahli materi yang melakukan pengujian yaitu Guru Mata Pelajaran Teknologi Jaringan Berbasis Luas (WAN).

Validasi ahli materi meliputi dua aspek yaitu aspek kualitas materi dan aspek kemanfaatan materi. Grafik hasil validasi oleh ahli media ditunjukkan seperti gambar dibawah ini:

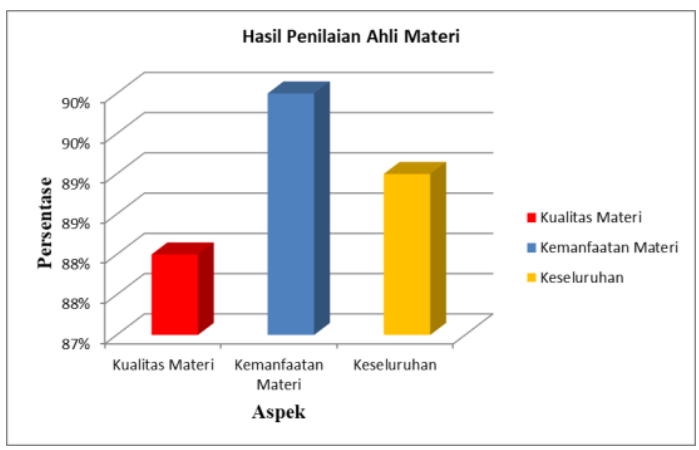

Gambar 6 Grafik Penilaian Ahli Materi

Hasil penilaian ahli materi ini ditinjau dari aspek (1) Kualitas materi, memperoleh persentasi (88\%) dan (2) Kemanfaatan materi memperoleh persentasi (90\%). Secara keseluruhan tingkat validasi materi pembelajaran video tutorial memperoleh persentasi $(89 \%)$ berada pada skala 1 . Jadi video tutorial ini dilihat dari materinya dikategorikan sangat layak diproduksi tanpa revisi.

3. Pengujian Terhadap Peserta Didik

a. Ujicoba skala kecil

Ujicoba skala kecil digunakan untuk mengetahui pemahaman peserta didik terhadap langkah-langkah mengkonfigurasi peralaatan WAN sebelum dilakukan ujicoba dalam skala besar. Ujicoba skala kecil dilakukan pada 12 siswa. Siswa yang digunakan dalam ujicoba skala kecil diambil yaitu 4 siswa yang nilainya paling rendah, 4 siswa yang nilainya standard dan 4 siswa yang nilainya tertinggi.

Grafik hasil ujicoba skala kecil ditunjukkan seperti gambar dibawah ini: 


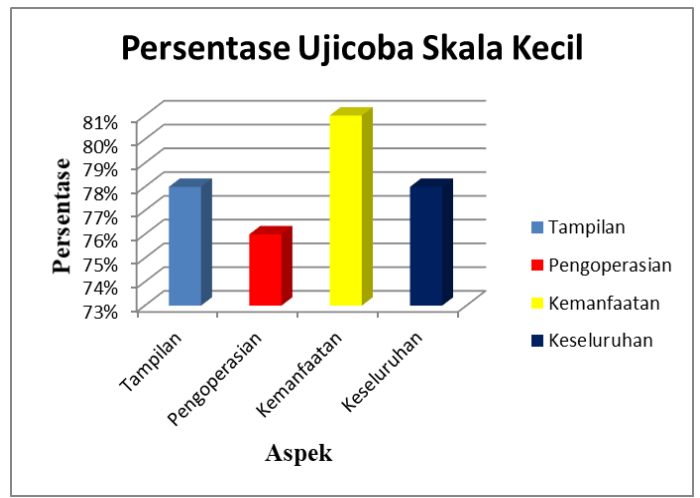

Gambar 7 Grafik Hasil Ujicoba Skala Kecil

Hasil ini menunjukkan bahwa Media Pembelajaran yang dikembangkan berdasarkan ujicoba skala kecil secara keseluruhan dalam kategori sangat layak digunakan dalam pembelajaran (78\%). Ujicoba skala kecil tidak memberikan revisi pada media pembelajaran, namun dibuat catatan tersendiri untuk membuat video tutorial yang lain. Pada uji skala kecil dapat diketahui bahwa dari duabelas siswa yang diujicobakan memberikan dampak yang positif pada siswa.

b. Ujicoba skala besar

Sebelum melakukan ujicoba skala besar media yang sudah divalidasi oleh ahli media dan ahli materi dilakukan revisi. Dari ahli materi menilai bahwa media tidak perlu dilakukan revisi. Tapi dari ahli media menyarankan untuk melakukan revisi sebagai berikut: (1) Judul media ditampilkan (2) Memberikan efek pada transisi video

Uji coba skala besar dilakukan untuk mengetahui tingkat pemaham siswa terhadap materi yang disajikan menggunakan media video tutorial yang sudah dibuat. Untuk ujicoba skala besar dilakukan pada 30 siswa yaitu kelas XI TKJ SMK Negeri 1 Kempas.
Grafik hasil ujicoba skala besar ditunjukkan seperti gambar dibawah ini:

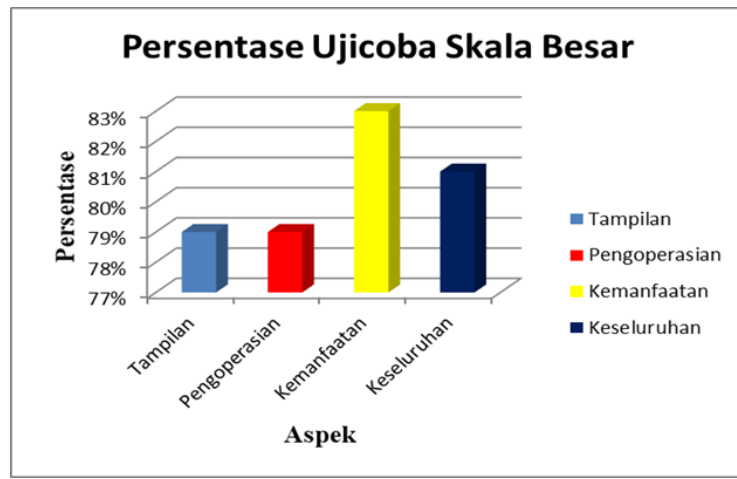

Gambar 8 Grafik Hasil Ujicoba Skala Besar

Berdasarkan grafik di atas dapat diketahui persentase hasil ujicoba skala besar untuk tiap-tiap aspek. Hasil ini menunjukkan bahwa Media Pembelajaran yang dikembangkan berdasarkan ujicoba skala besar secara keseluruhan dalam kategori sangat layak digunakan dalam pembelajaran $(81 \%)$. Pada uji skala besar dapat diketahui bahwa dari tiga puluh siswa yang diujicobakan memberikan dampak yang positif pada siswa.

Tahapan Proses yang terakhir adalah distribution. Pendistribusian video pembelajaran dilakukan dengan cara memberikan langsung ke siswa dan di upload di youtube agar bisa diakses oleh masyarakat luas yang membutuhkan.

Proses pembelajaran menggunakan video tutorial ini dilakukan di dalam kelas atau laboratorium komputer sebelum siswa melakukan praktik. Siswa diminta melihat dan mendengarkan video pada layar yang telah disediakan. Selain itu, video juga dapat dibawa ke rumah untuk diputar menggunakan HandPhone ataupun laptop sehingga memudahkan siswa untuk belajar dirumah. 
Untuk mengetahui sejauh mana keefektifan penggunaan video tutorial terhadap hasil belajar siswa dalam mata pelajaran Teknologi Jaringan Berbasis Luas (WAN) kelas XI SMK Negeri 1 Kempas maka dilakukan evaluasi. Penilaian dilakukan dengan menggunakan bantuan media video tutorial. Penilaian dilakukan langsung oleh guru dengan menilai hasil konfigurasi anak setelah melakukan praktikum. Berdasarkan penilaian guru, diperoleh skor rata-rata 78 . Padahal sebelum menggunakan video pembelajaran skor rata-rata 68. Dari data tersebut terjadi peningkatan hasil belajar sebesar 15\%. Maka berdasarkan penelitian yang dilakukan hipotesisnya dapat diterima. Dengan perolehan skor rata-rata 78 artinya siswa kelas kelas XI SMK Negeri 1 Kempas yang mendapat pembelajaran dengan bantuan video tutorial lebih tinggi nilainya bila dibandingkan dengan pembelajaran sebelumnya (tanpa menggunakan video tutorial).

\section{PENUTUP}

Berdasarkan hasil penelitian dan pembahasan pada pengembangan media pembelajaran, maka dapat ditarik kesimpulan sebagai berikut: (1) Pengembangan Media Pembelajaran Video Tutorial dikembangkan dengan enam tahap yaitu concept, design, material collecting, assembly, testing, dan distribution. Media Pembelajaran Video Tutorial sangat layak dikembangkan sesuai dengan pendapat dari ahli media maupun ahli materi. (3) Media Pembelajaran Video Tutorial dapat meningkatkan pemahaman dan ketertarikan peserta didik terhadap materi yang disampaikan.

Adapun saran yang dapat penulis berikan adalah (1) Media Pembelajaran Video Tutorial pada Kompetensi Dasar Mengkonfigurasi Jaringan Nirkabel pada Mata Pelajaran Teknologi Jaringan Berbasis Luas (WAN) sebaiknya digunakan guru dalam kegiatan belajar mengajar sehingga proses pembelajaran menjadi lebih menarik dan menyenangkan. (2) Media Pembelajaran Video Tutorial pada Kompetensi Dasar Mengkonfigurasi Jaringan Nirkabel pada Mata Pelajaran Teknologi Jaringan Berbasis Luas (WAN) sebaiknya digunakan siswa untuk belajar mandiri di rumah dengan memanfaatkan Komputer, Laptop atau Handphone untuk belajar. (3) Pengembangan Media Pembelajaran pada Mata Pelajaran Teknologi Jaringan Berbasis Luas (WAN) perlu dilakukan lebih lanjut pada materi yang lain guna meningkatkan inovasi dan variasi terhadap penggunaan Media Pembelajaran. (4) Guru sebaiknya terus mempelajari tentang pembuatan video tutorial agar dapat menciptakan video tutorial lebih baik dan menarik.

\section{DAFTAR PUSTAKA}

Arikunto, Suharsimi. 1993. Manajemen Penelitian. Jakarta: PT. Raja Grafindo Persada.

Arikunto, Suharsimi. 2013. Prosedur Penelitian: Suatu Pendekatan Praktik. Jakarta: Rineke cipta.

Binanto, Iwan. 2010. Multimedia DigitalDasar Teori dan Pengembangannya. Yogyakarta: Andi.

Daryanto. 2007. Evaluasi Pendidikan. Jakarta:Rineka Cipta.

Dinata, Yogi Nurcahyo. 2013. Penggunaan Media Pembelajaran Video Tutorial Untuk Meningkatkan Hasil Belajar Siswa Teknik Gambar Bangunan Smk N 1 Seyegan Pada Mata Pelajaran Menggambar Dengan Autocad. Jurnal Skripsi. Jurusan Pendidikan Teknik Sipil Dan Perencanaan: Universitas Negeri 
https://eprints.uny.ac.id/21667I. (diunduh 15 Agustus 2019).

Efendi, A., Sumarni, S., \& Efendi, Agus. 2016. Pengembangan Media Pembelajaran Berbasis Video Tutorial Pada Mata Kuliah Mekanika Tanah. Indonesian Journal of Civil Engineering Education, Vol. 2, No. 1. https://jurnal.uns.ac.id/ijcee/article/dow nload/11198/10018. (diunduh 6 Agustus 2019).

Hamalik, Oemar. 2006. Proses Belajar Mengajar. Bandung: Bumi Aksara.

Iqra' al- Firdaus. 2010. Buku Lengkap Tuntunan Menjadi Kameramen Profesional. Yogyakarta: BukuBiru.

Jihad, Asep \& Haris, Abdul. 2013. Evaluasi Pembelajaran. Yogyakarta : Multi Pressindo.

Miarso, Yusufhadi. 2011. Menyemai Benih Teknologi Pendidikan. Jakarta: Kencana Prenada Media Group.

Muzakki, Ahsan. \& Putu Asto Buditjahjanto, I Gusti. 2015. Pengembangan Media Pembelajaran Video Tutorial Teknik Pemrograman Kelas X Bidang Keahlian Teknik Audio Video SMK Negeri 1 Madiun. Jurnal Pendidikan Teknik Elektro. Volume 04 Nomor 02. halaman 375 381.

https://jurnalmahasiswa.unesa.ac.id/in dex.php/jurnal-pendidikan-teknikelektro/article/viewFile/11428/4437. (diunduh 13 Agustus 2019).

Nasution, S. 1990. Berbagai Pendekatan dalam Proses Belajar Mengajar. Jakarta: Bina Aksara.
Nasution, S. 2013. Berbagai Pendekatan dalam Proses Belajar Mengajar. Jakarta: Bina Aksara.

Pramudito, Aria. 2013. Pengembangan Media Pembelajaran Video Tutorial pada Mata Pelajaran Kompetensi Kejuruan Standar Kompetensi Melakukan Pekerjaan dengan Mesin Bubut Di Smk Muhammadiyah 1 Playen. Jurnal Skripsi. Jurusan Pendidikan Teknik Mesin: Universitas Negeri Yogyakarta. https://eprints.uny.ac.id. (diunduh 16 Agustus 2019).

Riyana, Cepi. 2007. Pedoman Pengembangan Media Video. Jakarta: P3AI UPI.

Rudi, Susilana \& Riyana, Cepi. 2008. Media Pembelajaran. Bandung: Jurusan Kurtekpend FPI UPI.

Rusman. 2012. Belajar dan Pembelajaran Berbasis Komputer. Bandung: Alfabeta.

Rusman. 2014. Model-Model Pembelajaran. Jakarta: PT. Rajagrafindo.

Sanaky, AH Hujair. 2013. Media Pembelajaran Interaktif-Inovatif. Yogyakarta: Kaukaba Dipantara.

Sanjaya, Wina. 2011. Strategi Pembelajaran Berorientasi Standar Proses Pendidikan. Jakarta: Prenada Media.

Sanjaya, Wina. 2014. Media Komunikasi Pembelajaran. Jakarta: Kencana Prenada Media Group.

Sudjana, Nana \& Rivai, Ahmad. 2011. Media Pengajaran, Bandung: Sinar Baru Algensindo. 
Sukiman. 2012. Pengembangan Media

Pembelajaran. Yogyakarta: PT. Pustaka Insan Madani.

Sumantri, Mohamad Syarif. 2015. Strategi Pembelajaran, Kota Depok: PT Rajagrafindo.

Tim Redaksi Pusat Bahasa Depdiknas. 2001. Kamus Besar Bahasa Indonesia. (Edisi ketiga). Jakarta : Balai Pustaka.

Winkel,W.S. 1987. Psikologi Pengajaran. Jakarta : Gramedia.

Yana, Baiq Ade Irma Willi., Kholisho, Yosi Nur., \& Fathoni, Ahmad. 2018. Pengembangan Media Pembelajaran Berbasis Video Tutorial Interaktif pada Mata Pelajaran Teknik Animasi 2 Dimensi. EDUMATIC: Jurnal Pendidikan Informatika. Volume 2, Nomor 2. halaman 52 - 58. e-journal. hamzanwadi. ac.id. (diunduh 14 Agustus 2019). 